\title{
The Effect of Instruction Based on Multiple Intelligences Theory on the Attitude and Learning of General English
}

\author{
Habib Soleimani ${ }^{1}$, Ahmad Moinnzadeh ${ }^{1}$, Zohreh Kassaian ${ }^{1}$ \& Saeed Ketabi ${ }^{1}$ \\ ${ }^{1}$ University of Isfahan, Isfahan, Iran \\ Correspondence: Habib Soleimani, University of Isfahan, Isfahan, Iran. Tel: 98-918-888-6179. E-mail: \\ h181352@yahoo.com
}

Received: November 22, 2011 Accepted: July 2, 2012 Online Published: July 25, 2012

doi:10.5539/elt.v5n9p45 URL: http://dx.doi.org/10.5539/elt.v5n9p45

\begin{abstract}
The purpose of the present study is investigating the effect of instruction based on Multiple intelligence (MI) theory on attitude and learning of General English course among students of Islamic Azad University, Kermanshah Branch in the second semester of educational year of 2010-2011. 61 male and female students in two different classes participated in the present study that were assigned to experimental ( 32 students) and control (29students) groups based on random cluster sampling. A quasi experimental method of research with a pre- and post test was used. The experimental group was taught according to the theory of MI and the control group was instructed based on the traditional method of teaching General English in eight weeks time. In order to determine the effect of MI-based instruction compared with traditional method, a researcher constructed test including 30 items were utilized. In order to assess the attitude of the learners toward English, a 15 items scale of attitude toward English Language was also employed. For analyzing data we used ANCOVA and independent sample t-test. The results of the study indicated that there was a significant difference between improving in General English course between experimental and control groups. In other words, students taught based on MI theory exceeded the traditionally instructed students both in general and in each sub-skill of learning English (vocabulary, reading comprehension, and structure). The results also indicated that attitude of students towards learning English in experimental group improved significantly.
\end{abstract}

Keywords: multiple intelligence-based instruction, attitude towards English, improvement in learning English

\section{Introduction}

The theory of Multiple intelligence was proposed by Howard Gardner in 1980's .This theory has important implications for teaching in general and for language learning in particular. (Armstrong 2007; Azar 2006; Buchen 2006; Campbell \& Dickinson 2004; Christian 2004; Fogarty \& Stoehr 2007; Tracy \& Richery 2007; Viens \& Kallenback 2004; Barrington 2004; Chan 2006; Christion \& Kennedy 2004; Hall 2004). Gardner defines intelligence as "the ability to process information that is activated in a cultural contest for problem solving or creating products which are worthy in a culture”. (Gardner 1999, p. 33)

Gardner introduces 8 distinct intelligences which include verbal linguistic, logical-mathematical, visual-spatial, bodily-kinesthetic, musical, interpersonal, intrapersonal, andnaturalistic. (Gardner 1999; Armstrong 2000; Ormrod 2006; Peariso 2008)

After the introduction of MI theory, changes have been made in curriculum and teaching methodology of schools. Many government and private institutions based their curriculum on MI theory after the publication of Frames of Mindby Gardner in 1983. Recently MI theory has been considered in language teaching .Language teacher started to relate MI model with learning styles and to consider the benefits of using MI theory to enhance learner's abilities individual needs. According to Snider (2001) MI theory-related materials have the strong potential to improve foreign language (FL) instruction because theory engage learner's innate abilities. (p. 6)

By applying MI theory EFL/ESL teachers can address the great diversity in learner, develop learner's intelligences and "create an individualized learning environment". (Christison, 1996. p. 10)

Richard and Rodgers (2001) define MI theory as a way that not only have been attended to in public instruction but also in teaching English and its application in teaching English is recent and new. (p. 117) .Nowadays one of the problems of education is lack of interest and motivation and difficulty of students in special course including 
English whose main consequence is weak educational performance in the related course.

However, many learners have difficulty in using English correction and independently in reading, writing, speaking, and meaningful communication (Bell, Ziegler, \& McCallum, 2004; Curtin, 2005). Several factors can be mentioned as the reason for this lack of interest and weak performance among which, lack of cognitive approaches in teaching can be mentioned (Klinger, Artiles, and Mendez Barletla, 2006). The current strategies in teaching English are mainly on memorizing grammatical rules.

Memorizing strategy would lead to negative consequences in fluency and social skills which learners need during the process of learning English for development (Harris and Grenfell, 2004).This problem would be intensified without providing teaching strategies for language learning programs (Barrington, 2004; Lightbown \& Spada, 2006; Lombardi, 2008; Lujan, 2008).

MI theory can be a new and effective method for presenting different strategies of teaching and can help students achievements ameliorated. (Barrington 2004; Kornhaber, Fierros, and Veenema 2004; Cohen \& Weaver 2004; Curtin 2005; Mitchel \& Myles 2006; Oxford, Cho, Leung, \& Kim 2004; Oxford \& lee 2008).

While previous researches have investigated the effect of MI on learning language, more studies are needed for explaining the application of MI theory in improving language learning particularly in higher education. In spite of emphasizing language skills, examination results are indicative of decreasing language learning (Chan 2008). Detecting language learning problems need presenting solutions such as using MI theory as an instructional plan (Armstrong 2007; Fugarti \& Stoehr 2007). Therefore, the present study is going to investigate the effect of such an approach on learning improvement and attitudes towards general English course. As a result, the problem is whether there is a difference between MI-based instruction and traditionally based teaching which emphasize just verbal-linguistic intelligence on learning and attitude towards English course among the students. In other to answer this problem the following question were posed.

1. Is there any difference between MI-based teaching and traditional way of instruction among students in improving structure in general English course?

2. Is there any difference between MI-based teaching and traditional way of instruction among students in improving vocabulary in general English course?

3. Is there any difference between MI-based teaching and traditional way of instruction in improving reading comprehension ability of students' in general English course?

4. Is there any difference between MI-based teaching and traditional way of teaching in students' attitude towards learning English?

\section{Method}

\subsection{Population}

The populationof this study are all students in Islamic Azad University of Kermanshah who had taken general English as one of the courses of that semester.

\subsection{Participants and Sampling}

The participants of this study include 61 students. 29 students were assigned as the control group and 32 of them to experimental group according to random cluster sampling. From among the classes which had general English, two were selected to work for experimental and control groups.

\subsection{Design}

Due to the fact that in the present study the effectiveness of teaching based on MI theory on learning and attitudes towards general English compared with the traditional way of teaching English is investigated, aquasi-experimental method of research was used which is considered an applied method of research. The design of the study is a two heterogeneous groups with pre and post test. In this kind of design the groups will set up in advance. The participants took part in a pre-test. (see table 1)

Table 1. Design of the study

\begin{tabular}{llll}
\hline Group & Pre-test & Experiment treatment & Post test \\
\hline Experimental group & $\mathrm{T} 1$ & $\mathrm{X}$ & $\mathrm{T} 1$ \\
Control group & $\mathrm{T} 2$ & - & $\mathrm{T} 2$ \\
\hline
\end{tabular}

\subsection{Instruments}

The instruments for this study consisted of: 
1. An achievement test of learning English: This was an achievement teacher made test which was composed of 30 items that tested structure, vocabulary and reading comprehension. Thereliability and validity of the test were measuredand validated by experts of education and psychometrics. The reliability coefficient was measured through Cronbach alpha. It was calculated to be 0.71 which is an acceptable amount.

2. An attitude test towards English course: This researcher made instrument was consisted of 15 items. Each item was answered based on the 5 level Likert scale form completely disagrees to completely agree. These options were scored from1-5. Content validity of this test was also approved by educational and psychometric experts. The reliability of the test was also calculated through Cronbach alpha and the amount was calculated to be .76 .

\subsection{Procedure}

In order to determine the effectiveness of MI-based instruction of general English to students, two classes were chosen and randomly assigned as experimental and control groups.

As the pre-test, two teacher made tests was administered: 1. A teacher-made achievement test was used for measuring the amount of learning which had the sub-test of structure (10 items), vocabulary (10-items) and reading comprehensive (10-items) and 2. A test of attitude towards English.

The experimental group were taught by the instructor (researcher) who was familiar with the principles of MI-based teaching. The researcher had provided lesson plans related to general English prepared according to the MI principles and procedures. The control group were taught based on the traditional way of teaching English.At the end of the semester a post- test was given to both groups who had been taughtthe same contents by the same instructor.

\subsection{Data Analysis}

Some descriptive statistics, (frequencies, mean, standard deviation and standard error) and inferential statistics (analysis of variance, analysis of covariance, and independent sample t-test) were used to analyze the data gathered from pre- test and post -test of experimental and control groups in order to compare the effect of instruction based on MI with traditional way of teaching on achievement and attitude towards learning English in the sub-skill of structure,vocabulary and reading comprehension. The reason for using this test is statistical control of the first differences of participants and removing the effects of unpredictable variables in order to test experiment. The reason of using pre-test here was controlling and removing these differences.

\section{Results}

\subsection{Descriptive Statistics}

The descriptives in table 2 indicates that in general the scores of the experimental group in post- test are higher than the scores of the control group.As it can also be observed we see the scores of experimental group are higher in the sub-tests of vocabulary, reading comprehension and structure. (see table 2)

Table 2. Frequency, distribution, mean and standard deviation of the participants taken part in pre-test and post-test of general English in different sub-skills

\begin{tabular}{lllllc}
\hline \multicolumn{1}{c}{ Test -type } & Group & No & mean & SD & Std. error \\
\hline \multirow{2}{*}{ Pretest, Total } & Experimental & 32 & 6.1 & 2.115 & 0.347 \\
\hline \multirow{2}{*}{ Post, Total } & Control & 20 & 407 & 2.31 & 0.42 \\
\hline Pretest, & experimental & 32 & 11.2 & 4.146 & 0.73 \\
Vocabulary & Control & 20 & 8.5 & 3.64 & 0.67 \\
\hline Post-test, vocabulary & experimental & 32 & 5.35 & 2.25 & 039 \\
& Control & 29 & 3.5 & 2.06 & 0.38 \\
\hline Pretest ;Reading & Control & 32 & 8.1 & 3.19 & 0.56 \\
Comprehension & Control & 29 & 4.5 & 2.70 & 0.50 \\
\hline Post-test; Reading & experimental & 32 & 2.5 & 1.05 & 0.18 \\
Comprehension & Control & 29 & 1.90 & 1.19 & 0.22 \\
\hline \multirow{2}{*}{ Pretest; structure } & experimental & 32 & 0.17 & 1.25 & 0.22 \\
\hline \multirow{2}{*}{ Post-test; structure } & Control & 29 & 0.3 & 0.38 & 0.21 \\
\hline
\end{tabular}

The results in table 3 indicates that scores of the experimental group in the attitude test are higher compared with control group. As it is seen the scores of the experimental group in the attitude test in the pre- test is 62 while in 
post-test it has increased two 66.43 while in the control group this difference is from 52.03 pre-test to 52.43 in post- test. (see table 3)

Table 3. Frequency distribution, mean and standard deviation of participants score in pretest and post-test of attitudes toward English

\begin{tabular}{llllll}
\hline & groups & NO & Mean & SD & Std. error \\
\hline pretest & experimental & 32 & 62 & 2.16 & 12.3 \\
& control & 20 & 52.03 & 12.60 & 2.34 \\
\hline \multirow{2}{*}{ Post test } & experimental & 32 & 66.43 & 2.05 & 11.64 \\
& control & 29 & 52.93 & 13.08 & 2.43 \\
\hline
\end{tabular}

\subsection{Findings Related to Research Question}

The results of table 4 show that the pre-test variable significantly correlated with the dependent variable. Therefore, for adjusting the effect of covariate variable, we used analysis of covariance, the result of which indicates that the effect of independent variable after adjusting the effect of dependent variable is significant so that the calculated $F$ with the amount 29.23 with df of 58 and 1 is larger than the critical amount which is 8.34. As a result at the .01 level of significance it can be claimed that instruction based on Multiple intelligence theory and procedures has had a significant effect on the learning of general English among students.

Table 4. Covariance analysis for achievement in learning English for the experimental and control groups

\begin{tabular}{llllll}
\hline Source ofVariation & Sum of Squares & $\mathrm{df}$ & Mean Square & $\mathrm{F}$ & \\
\hline Covariates(pretest) & 342.67 & 1 & 342.67 & 64.45 & .000 \\
Group & 155.40 & 1 & 155.40 & 29.23 & .000 \\
Residual (Error) & 308.39 & 58 & 5.32 & & \\
Total & 7107.52 & 61 & & & \\
\hline
\end{tabular}

The results of analyzed data for the sub-test of structure, vocabulary and reading comprehension are shown in tables 5, 6, and 7 respectively.

Table 5. Analysis of covariance for comparing experimental and control groups on the sub-test of structure

\begin{tabular}{llllll}
\hline Source ofVariation & Sum of Squares & df & Mean Square & F & P \\
\hline Covariates(pretest) & 63.81 & 1 & 63.81 & 170.47 & .000 \\
Group & 26.83 & 1 & 26.83 & 71.68 & .000 \\
Error & 21.709 & 58 & .374 & & \\
Total & 555.615 & 61 & & & \\
\hline
\end{tabular}

Table 6. Analysis of covariance for comparing experimental and control groups in the sub-skill of vocabulary

\begin{tabular}{llllll}
\hline Source ofVariation & Sum of Squares & df & Mean Square & F & P \\
\hline Covariates(pretest) & 281.72 & 1 & 281.72 & 68.44 & .000 \\
Group & 41.053 & 1 & 41.053 & 9.97 & .000 \\
Residual (Error) & 238.735 & 58 & 4.12 & & \\
Total & 325.625 & 61 & & & \\
\hline
\end{tabular}

Table 7. Independent sample t-test for comparing the experimental and control groups in the sub-skill test of reading comprehension

\begin{tabular}{lllllllll}
\hline Group & $\mathrm{N}$ & Mean & Std. division & Std. error & $\begin{array}{l}\text { Mean } \\
\text { difference }\end{array}$ & $\mathrm{T}$ & $\mathrm{df}$ & sig \\
\hline experimental & 32 & .86 & .72 & .13 & & & & \\
Control & 29 & .41 & .488 & .91 & .465 & 2.95 & 55 & .004 \\
\hline
\end{tabular}

Table 5 indicates that the covariate variable (pre-test) has a meaningful relationship with dependent variable. Therefore, a covariance test was used for adjusting the effect ofcovariatevariable and as the results show the 
effect of the independent variable after adjusting the effect of covariatesvariable is significant. As it is also seen in table 4 the amount of calculated $F$ which is 71.68 with the $\mathrm{df}$ of 1 and 58 is larger than the critical amount which is 8.34 . Therefore, at the .01 level of significance it can be said that teaching structure of general English to students based on Multiple intelligence theory and procedures has had a meaningful effect. The adjusted means are also observed in table 6 .

The results for comparing experimental and control groups in vocabulary sub-skill test indicated in table 6 show that the effect of covariatevariable is significant. As it is observed the calculated $F$ which is 9.97 with adf of 1 and 58 is larger than the critical $F$ which is 8.34 . Therefore, it can be said that there is a significant difference between Multiple Intelligence based-teaching and traditional way of teaching at the .01 level of significance. Since the assumption of analysis of covariance is assuming the two assumptions of the homogeny of regression curve and variances, this assumptions was not obtained. Therefore, an independent sample t-test was applied in order to compare the experimental and control groups. Table 7 indicates independent sample t-test for comparing experimental and control groups in the sub-skill test of reading comprehension.

As it can be seen in table 7, there is a significant difference in the scores of experimental and control groups in the sub-skill test of reading comprehension. The t-observed which is 2.95 with the $\mathrm{df}$ of 55 is larger than the critical amount which is 2.16 . Therefore, with a $99 \%$ confidence it can be claimed that the research hypothesis claiming the existence of difference between MI-based instruction of reading comprehension compared with the traditional ways of teaching is accepted at the $P$ value of .01 .

The observed results in table 8 indicate a significant relationship between independent and the dependent variables. Therefore, analysis of covariance was used for adjusting the effect of dependent variable. The results are also indicative of a signification effect of independent variable after adjustingthe effect of covariate variable. It is seen that the $F$ calculated (13.41) with a df of 1 and 58 is larger than 8.34. Therefore, again at the .01 level of significance it can be claimed that Multiple Intelligence-based instruction has a meaningful effect on the attitudes of students towards learning English.

Table 8. Analysis of covariance for comparing experimental and control groups in the attitudes towards English course.

\begin{tabular}{llllll}
\hline Source ofVariation & Sum of Squares & $\mathrm{df}$ & Mean Square & $\mathrm{F}$ & $\mathrm{P}$ \\
\hline Covariates(pretest) & 8032.179 & 1 & 8032.179 & 481.48 & .000 \\
Group & 223.74 & 1 & 223.74 & 13.41 & .000 \\
Residual (Error) & 967.558 & 58 & 16.7 & & \\
Total & 231.495 & 61 & & & \\
\hline
\end{tabular}

\section{Discussion \& Results}

The purpose of the present study is investigation and comparison of the effect of teaching general English course based onMultiple intelligence and traditional way of teaching on achievement in learning English and attitudes towards English course.Based on this, the problem which was posed was whether there is a difference between MI-based instruction and achievement and attitudes towards English course among students. Analysis of the statistical results indicates that there is statistical difference between mean scores of the experimental and control groups in pre-test and post- test.Consequently it can be said that generally there is a meaningful difference between Multiple Intelligence based teaching and traditional-based teaching in achievement of English course in students. In other words, instruction based on Multiple intelligence in comparison with traditional way of teaching has been more effective. Moreover in each of the three sub-skills of vocabulary, structure and reading comprehension there is a significant difference between post-tests of experimental and control groups. Therefore we can say that there is a significant difference in teaching based on Multiple intelligence and traditional ways of teaching in learning English in students in the sub-skills of vocabulary, structure and reading comprehension. The results of this study is consistent with the results of other studies done in this area.Farjami (2002) has investigated the effect of utilization of Multiple intelligence activities and content instructional passages on general English of university learners. He has pointed out that students performances have approved the hypotheses that using content passages in line with MI activities have improved general English performance in students compared with using general passages and traditional activities. It can be inferred that one of the reasons for effectiveness of this program on achievement in English is the fact that in this method learning activities are in line with each of the Multiple intelligence. Thus all learners will have the opportunity of learning 
the content.In this study there have been attempts to involve language learning activities which are more consistent with verbal-linguistic intelligence beside other kinds of intelligences.Consequently opportunities for learning were available for all learners.Saricaoglo \& Arikan (2009) have reported a negative relationship between achievement in structure and physical kinesthetic, spatial, and intrapersonal intelligences while they report a positive and meaningful relationship between reading comprehension and musical intelligence. Motallebzadeh and Manoochehri (2008) also tried to determine the amount of relationship between MI and reading comprehension in international IELTS in Iranian participants . They came to this understanding that for Iranian participants the only kind of significant relationship observed was between logical mathematical and reading comprehension from among the intelligences. The reason for this relationship is supposed to be the common nature of this kind of intelligence and the required activities involved in reading comprehension in second language. Bass and Byhan (2010) also have revealed that those students taught based on MI have gained more in achievement and are reported to be more motivated compared with those who have been instructed based on traditional ways of teaching.Moreover Abdolkader and Gundogdu (2009) have indicated the effectiveness of the MI-based programs on reading comprehension and vocabulary of students. Shearer (2004) in a research regarding the application of Multiple intelligence theory in English as a second language classrooms for university levels came to this conclusion that blending language courses with multiple intelligence caused autonomy in English learning for learner.Concerning the role of multiple intelligence approach in memorizing vocabulary Anderson (1998) indicated that the subjects' scores improved in vocabulary tests which were administered every other week.Moreover, both teacher and students awareness of learning styles and vocabulary memorization skills increased. Palmberg (2002) also showed how teachers engaging learners'multiple intelligence can satisfy their students' need with different intelligence abilities during the language instruction period (cited in Pishgadam and Moafian 2007). The results of the present study is also consistent with the studies of Akbari and Hosseini (2007), Barington (2004), Kornhaber, Fierros an Veenema (2004), Cohen and Weaver (2004), Curtin (2005), Mitchell and Myles (2006), Oxford, Cho, Leung and Kim (2004), Oxford and Lee (2008), Barrington (2004), Chan (2006), Christosen and Kennedy (2004), Christosen (1999, 2004), Hall (2004), Haj Hosseinnezhad and Baleghizadeh (2003) which have confirmed the effectiveness of instruction based on MI on achievement in English learning. To elaborate on the above findings, it can be said that making students aware of their intelligences and guiding them of the ways they would be more successful in learning paves the way for learners to learn study skills that consider their strengths and compensate their weaknesses.For example by nature-relatedmnemonics one can develop vocabulary knowledge of learners (Arnold and Fonesca, 2004). T elaborate on why MI is an effective method of instruction and is able to solve instructional problem Moran, Kornhaber, and Gardner (2006) have given the following example: "Think about Lego building blocks. If we have only one Lego, we can build just a limited structure of Lego. However, if we have different types and shapes of Lego, we would be able to build a network of connected structures. These structures make up various patterns and finally we can build complete plans.Multiple intelligence do the same in practice". (p. 26)

To support the above case Nolen (2003, p. 119) also suggests that regarding the fact that the intelligences are potentially available in every learner, offering an instructional material for a foreign language should consist all or most of the multiple intelligence.

Results gained from the effect of multiple intelligence-based teaching on the attitude towards English course among students show that there is a significant difference between the mean score of experimental group and that of the control group in the post test. To put it in another way, it can be said that multiple intelligence-based teaching has been more effective than traditional way of teaching in the students' attitude toward learning English. Hall's research (2004) shows that teachers who have utilized multiple intelligence-based instruction in second or foreign language classrooms have observed students been more satisfied and had more positive attitudes towards learning English in experimental than the control group. Emig (1997) has simulated multiple intelligence-based teaching to a miracle due to its advantages for the students and teachers, because the students feel comfortable and qualified in the classes. In this vein, Hall (2004) found out that multiple intelligence-based classrooms increases students educational progress in learning English and have positive effects on the attitude toward learning languages in students. To clarify this finding, one can say that in multiple intelligence-based teaching, learners learn because of their abilities and they are allowed to learn the way they have been taught themselves, learning would be pleasant to them. When there are various approaches and methods for obtaining educational aims and the learners find the content containing interesting activities, they learn it and experience less anxiety in addressing learning problems. Because students don't have to feel they don't know something in a multiple intelligence-based classroom, there would be a change in their attitude that removes the boundaries in learning effectively. Multiple intelligence framework help the learners gain better self-awareness about learning abilities in different intelligences areas. Goodnoughin a case study (2001) reports that $85 \%$ of students have 
declared that multiple intelligence-based teaching help them enjoy the lesson and learning. According to Billy (1999) utilizing multiple intelligence in classrooms can help teachers provide encouraging environment. (cited in Abdi, 2011) Generally, one can conclude that multiple intelligence-based teaching is more effective in learning and causes having a positive attitude towards English course. Therefore, it is suggested that seminars and courses be held for improving the use of multiple intelligence-based teaching so teachers can be aware of the effects of using this strategy in educational achievements and improving a positive attitude towards learning consequently they would be able to utilize this method in their classes.

\section{References}

Abdi, Ali. (2011). A comparison of the strategy of MI-based teaching and the classical way on achievement in experimental sciences course. Research and science innovations periodical, 9(37).

Abdulkader. F. A., \& Gundogdu. K. (2009). The effectiveness of a intelligences- based program on improving certin reading skills in $5^{\text {th }}$ - year primary learning disabled student. Electronic journal of research in educational psychology, 7(3), 673-690.

Akbari R., Hosseini. (2008). Multiple intelligence and language learning strategies: Investigating possible relations. Retrieved from www.sciencedirect.com

Anderson, A., \& T. Lynch. (1988). Listening. Oxford: Oxford University Press.

Armstrong, T. (2000). Multiple intelligence in the Classroom (2nd ed.). Alexandria, VA: Association for Supervision and Curriculum Development.

Armstrong, T. (2005). Special education and the concept of neurodiversity. NewHorizons for Learning Online Journal, XI(3), 1. Retrieved July 29, 2010, from the ProQuest database.

Armstrong, T. (2007). The curriculum superhighway. Educational Leadership, 64(8), 16-20. Retrieved May 31, 2010, from the EBSCOhost database.

ARNOLD. J., \& FONSECA. M. (2004). Multiple Intelligence Theory and Foreign Language Learning: A Brain-based Perspective. IJES, 4(1), 2004, 119-136.

Azar, A. (2006). Relationship of multiple intelligence profiles with area of constitution in high school and university entrance exam scores. Educational Administration: Theory \& Practice, 46, 157-174. Retrieved January 20, 2010, from the EBSCOhost database.

Barrington, B. (2004). Teaching to student diversity in higher education: how multiple intelligence theory can help. Teaching in Higher Education, 9(4), 422. Retrieved January 11, 2010, from the EBSCOhost database.

Barrington, E. (2004). Teaching to student diversity in higher education: how multiple intelligence theory can help. Teaching in Higher Education, 9(4), 421-434. http://dx.doi.org/10.1080/1356251042000252363

Bas. Gokhan. BEYHAN. Ömer. (2010). Effects of multiple intelligence supported project-based learning onstudents' achievement levels and attitudes towards English lesson. International Electronic Journal of Elementary Education, 2(3), July, 2010.

Bell, S. M., Ziegler, M., \& McCallum, R. S. (2004). What adult educators know compared with what they say they know about providing research-based reading instruction. Journal of Adolescent and Adult Literacy, 47, 542-563. Retrieved August 24, 2007, from the EBSCOhost database.

Buchen, I. H. (2006). Futures thinking, learning, and leading: Applying multiple intelligence to success and innovation. Lanham, MD: Rowman \& Littlefield Education.

Campbell, L., Campbell, B., \& Dickinson, D. (2004). Teaching and learning through multiple intelligence. Chicago, IL: Merill Company.

Chan, D. W. (2006). Perceived multiple intelligence among male and female Chinese gifted students in Hong Kong: The structure of the student multiple intelligence profile. The Gifted Child Quarterly, 50(4), 325. Retrieved February 10, 2010, from the EBSCOhost database. http://dx.doi.org/10.1177/001698620605000405

Chan, D. W. (2008). Giftedness of Chinese students in Hong Kong: Perspective from different conceptions of intelligences. The Gifted Child Quarterly, 52(1), 40. Retrieved August 2010, from the ProQuest database. http://dx.doi.org/10.1177/0016986207311058

Christion, M. A. (2004). Applying multiple intelligence theory: In perspective and in-service TEFL education programs. Forum, 36(2), 2. Retrieved February 3, 2010, from the ProQuest database. 
Christion, M. A., \& Kennedy, D. (2004). Multiple intelligence. TESOL Journal, 6(1), 349, 10-14. Retrieved February 3, 2010, from the EBSCOhost database.

Christison, M. A., \& D. Kennedy. (1999). Multiple intelligence: Theory and practice in adult ESL. National Clearinghouse for ESL Literacy Education Washington DC (ERIC Digest ED441350).

Christison, M. A. (1996). Teaching and learning languages through multiple intelligence. TESOLJournal, 6(1), $10-14$.

Cohen, A. D., \& Weaver, S. J. (2004). Styles and strategies-based instruction: A teachers' guide. Minneapolis, MN: Center for Advanced Research on Language Acquisition, University of Minnesota.

Curtin, E. (2005). Instructional styles used by regular classroom teachers while teaching.

Emig, V. B. (1997). A Multiple intelligence inventory.Educational Leadership, 55(1), 47-50.

Farjami, H. (2002). The applications of MI theory in designing activities and for teaching English. Unpublished MA dissertation. University of Semnan.

Fogarty, R., \&Stoehr, J. (2007). Integrating the curricula with multiple intelligence: Teams, themes, and threads (2nd. ed.). Thousand Oaks, CA: Corwin-Sage Press.

Gardner Howard. (1999). The Disciplined Mind: What All Student Should Understand. Simon and Schuster: New York.

Gardner, H., \& Moran, S. (2006). The science of multiple intelligence theory: Aresponse to Lynn Waterhouse. Educational Psychologist, 41, 227-232. http://dx.doi.org/10.1207/s15326985ep4104_2

Gardner, H. (1983). Frames of mind. The theory of multiple intelligence. New York. Basic Books.

Goodnough, K. (2001). Multiple intelligence theory: A framework for personalizing science curricula. School Science and Mathematics, 101(4), 180-193.

Haji Hussein nezhad, G. L., \& Baleghizadeh, S. (2003). A comparison of teaching based on Gardner's theory and traditional method on students performance in mathematics. Research on educational problems, Spring and Summer, 2003.

Hall, H. M. (2004). Learner-centered instruction and the theory of multiple intelligence with second language learners. Teachers College Record, 106(1), 63-180. Retrieved January 17, 2010, from the ProQuest database.

Harris, V., \& Grenfell, M. (2004). Language-learning strategies: A case for crosscurricular collaboration. Language Awareness, 13(2), 116. Retrieved January 19, 2007, from the EBSCOhost database. http://dx.doi.org/10.1080/09658410408667090

Klingner, J. K., Artiles, A. J., \& Méndez Barletta, L. (2006). English language learners who struggle with reading: Language acquisition or LD? Journal of Learning Disabilities, 39(2), 108-128. Retrieved June 29, 2007, from the ProQuest database.

Kornhaber, M. L., Fierros, E., \& Veenema, S. (2004). Multiple intelligence: Best ideas from theory and practice. Needham Heights, MA: Allyn \& Bacon.

Kornhaber, M. L., Fierros, E., \& Veenema, S. (2004). Multiple intelligence: Best ideas from theory and practice. Needham Heights, MA: Allyn \& Bacon.

Lightbown, P., \& Spada, N. (2006). How languages are learned (2nd. ed.). Oxford: Oxford University Press.

Lombardi, J. (2008). Beyond learning styles: Brain-based research and English language learners. Clearing House, 81(5), 219-222. Retrieved June 20, 2010, from the EBSCOhost database. http://dx.doi.org/10.3200/TCHS.81.5.219-222

Lujan, J. (2008). Linguistic and cultural adaptation needs of Mexican nursing students related to multiple-choice tests. Journal of Nursing Education, 47(7), 327-330. Retrieved June 20, 2008, from the EBSCOhost database.

Mitchell, R., \& Myles, F. (2006). Second language learning theories (2nd. ed.). London, UK, Hodder Arnold Press.

Moran, S., Kornhaber, M., \& Gardner, H. (2006). "Orchestrating Multiple intelligence”, Educational Leadership, September 2006. Retrieved May 18. 2009 from learn.esu10.org/mod/forum/discuss.php?d=506

Motallebzadeh, K., \& Manoochehri, M. (2007). An investigation of the relationship between multiple 
intelligence and reading comprehension ability in IELTS in Iranian learners. The principles of mental health journal, Summer issue, 2(11), 42-67.

Nolen, J. L. (2003). Multiple intelligence in the classroom. Education, 124(1), 115-120.

Ormrod, J. E. (2006). Educational Psychology: Developing Learners (5th ed.). Upper Saddle River, NJ: Pearson Prentice Hall.

Oxford, R. L., \& Lee, K. R. (2008). Understanding EFL learners' strategy use and strategy awareness. Asian EFL Journal, 10(1), 1. Retrieved August 13, 2010, from the EBSCOhost database.

Oxford, R. L., Cho, Y., Leung, S., \& Kim, H. J. (2004). Effect of the presence and difficulty of task on strategy use: An exploratory study. International Review of Applied Linguistics and Language Teaching, 42(1), 14-26. Retrieved June 20, 2010, from the EBSCOhost database.

Peariso. f. J. (2008). Multiple intelligence or Multiply Misleading: The Critic's View of the Multiple intelligence Theory. Liberty. University Spring.

Pishghadam, R., \& Moafian, F. (2006). The role of multiple intelligence profile of teachers of English in their success of teaching. Foreig language research, 42.

Richards, J., \& T. Rodgers. (2001). Approaches and methods in language teaching. Cambridge: Cambridge University Press. http://dx.doi.org/10.1017/CBO9780511667305

Saricaoglo, A., \& Arikan, A. (2009). Astudy of multiple intelligences, foreign language success and some selected variables. Journal of theory and practice in education, 5(2), 110-122. ISSN: 1304-9496.

Shearer, C. B. (2004). Using a multiple intelligence assessment to promote teacher development and student achievement. Teachers College Record, 106(1), 147-162. Retrieved June, 28, 2010, from the ProQuest database.

Sinder, D. P. (2001). Multiple intelligence Theory and foreign language teaching. Unpublished doctoral dissertation. University of utha.

Tracey, M., \& Richey, R. (2007). ID model construction and validation: A multiple intelligence case. Educational Technology Research \& Development, 55(4), 369-390. Retrieved July 29, 2008, from the EBSCOhost database. http://dx.doi.org/10.1007/s11423-006-9015-4

Viens, J., \& Kallenbach, S. (2004). Multiple intelligence and adult literacy: A Source book for practitioners. New York: Teachers College Press. 